ARTICLE

DOI: $10.1057 /$ s41599-018-0186-5

\title{
Bartlebys: Gothicizing office fiction
}

\author{
Masaomi Kobayashi ${ }^{1}$
}

\begin{abstract}
Gothic fiction is in essence about the power of place, particularly of house. If this obsessive focus on the house is found in other genres of fiction, Gothic fiction can certainly expand its realm of representation; namely, the extensive capacity of this genre can be illustrated by unveiling the Gothic nature of the seemingly non-Gothic. Herein lies why special attention is given to the office as an idiosyncratic kind of house in office fiction: fiction featuring such characters as clerks, civil servants, and company employees. In Gothicizing office fiction, Herman Melville's "Bartleby, the Scrivener: A Story of Wall-Street" draws parallels with Franz Kafka's "The Metamorphosis." These classics of nongenre fiction have hardly been considered the classics of office fiction. The primary emphasis of this study is on the international kinship between Melville's Bartleby and Kafka's Samsa: Bartleby's occupation of the law office turns the place into a house, and Samsa's transformation into the monstrous vermin turns his apartment into an office. These dual settings render each protagonist uncanny and ghostly. The discovery of parallels between the protagonists who embody work-life integration stems from incorporating not only elements typical of the Gothic, such as supernatural happenings and closed-room settings, but also other elements, especially work-life balance. This focus on work-life issues allows an exploration of another classic office-fiction story about an Asian Bartleby. Thus, cultivating an environment in which Bartleby's transnational cousins are rediscovered as Bartlebys lends itself to extending the scope of the Gothic. After all, Gothic fiction is an expanding universe in which the walls come tumbling down between office and house, between work and life, and even between the Gothic and the non-Gothic. The findings of this study highlight how every sphere of life, including work life, is potentially Gothicized.
\end{abstract}

\footnotetext{
${ }^{1}$ University of the Ryukyus, Okinawa, Japan. Correspondence and requests for materials should be addressed to M.K. (email: kmasaomi@edu.u-ryukyu.ac.jp)
} 


\section{Bartleby, Gregor, and Gothicizing}

othic fiction is essentially about the power of place, and in particular of house. In The Pleasures of Reading, Catherine Sheldrick supplies the following definition:

Gothic fiction is a genre obsessively focused on the house. "Last night I dreamt I went to Manderley again" is the famous first sentence of Daphne du Maurier's Rebecca (1938). In some other kinds of stories, the house is a place of safety, a sanctuary from the world. But not in gothic fiction, where interior spaces become prisons for imperiled heroines or represent a domestic happiness from which the scarred male protagonist is excluded. Naturally, the house in question is not just any house but a very impressive architectural monument, usually a castle but sometimes a monastery, convent, prison, or insane asylum. (2014, p. 65)

If this obsessive focus on the house is found in "some other kinds of stories," Gothic fiction can certainly expand its realm of representation. To put it another way, the extensive capacity of this genre can be illustrated by unveiling the Gothic nature of the seemingly non-Gothic. Herein lies why special attention will be given to the office as an idiosyncratic kind of house in office fiction: fiction featuring such characters as clerks, civil servants, and company employees, all of whom are far from what William Hughes refers to as stock characters in the Gothic- "the villainous Gothic Hero, the virtuous hero, and the imperiled heroine" (2013, p. 64). An attempt is thus made in this study to Gothicize office fiction so as to broaden the scope of the Gothic. The text that plays an integral part in achieving this aim is Herman Melville's 1853 story, "Bartleby, the Scrivener: A Story of WallStreet." Reading this classic tale of the titular character as the Gothic may sound challenging. It is not only because it does not center on any typical hero in the Gothic, but also because it is not set in any house in general, let alone any monumental building. Most of the action takes place in a law office-a place where the uncanny is most unlikely to occur. The office is located upstairs at Wall Street, and Bartleby turns this place to work into a place to live, namely a house. This office-house relationship is of pivotal importance to the Gothicization of "Bartleby." Naturally, then, one may ask if the same is true for other office-fiction stories. In order to answer this question in the affirmative, we must first think about how to diversify Bartleby.

As Nikil Saval points out in his essay "Bartlebys All!," Bartleby and his literary cousins are characterized by how they feel about their work rather than how they do it, and "if there is a politics of the white-collar novel in the United States, it is this: office fiction is deliberately and narrowly construed as being about manners, sociability, gossip, the micro-struggles for rank and status-in other words, 'office politics'-rather than about the work that is done in offices" (2014, p. 22). More must be said about office fiction, however. In fact, Bartlebys include not only those who occupy themselves with office politics, but also those who occupy office spaces. In regrouping office-worker characters under the name "Bartlebys," the current study excludes those like David Bell, the executive protagonist of Don DeLillo's 1971 novel, Americana. "[H]ow much did you know," he asks, "and how safe did you feel, about, for instance, your wife? And it was at that time, before we remembered why we were there, that the office surrendered a sense of belonging, and we sat in the early afternoon, pitching gently, knowing we had just returned to the mother ship" (DeLillo, 2011, p. 20). While making himself at home in his office, he has made his home with his wife, which means that the dividing line between his work life and his home life is still there. The office is hardly as vital to Bell as to Bartleby, and hardly does it play as crucial a role in Americana as it does in Gothicizing "Bartleby." Since Bartleby confines himself to the office, his story becomes inevitably Gothicized. This is also the case with newly defined Bartlebys, who can appear anywhere, not just in "the white-collar novel in the United States. ${ }^{1}$ Taken together, their stories of confinement emerge as a site to think widely about the Gothic. "Bartleby" is hence illustratively compared to its 1915 international counterpart, "The Metamorphosis," arguably the best-known work of Franz Kafka.

Kafka's story tells of Gregor Samsa, a traveling salesman confined to his room where he finds himself as some monstrous kind of vermin. As will be seen later, his confinement transforms his apartment house from a place to live into a place to work-an office. The story is generally acknowledged as an absurdist and existentialist masterpiece, but given its closed-room setting associated with the supernatural happening, it can be read as an office-fiction story that contains elements of the Gothic. In light of this dual structure, "The Metamorphosis" is indeed worth drawing parallels with "Bartleby." In The Silence of Bartleby, Dan McCall, the coiner of the term "the Bartleby Industry," examines a wide variety of approaches to "Bartleby." By so doing, he points to the paradox that "there never could have been 'a key" (1989, p. 30). Even if there cannot be found any key to the interpretation of "Bartleby," however, one can surely find an affinity between the story and another story, "The Metamorphosis." This intertextual interpretation will contribute to moving from an exclusive microcosm to an inclusive macrocosm-from the Bartleby Industry to the vast universe of the Gothic.

The English translation of "The Metamorphosis" was first published in 1933, and it was just eighty years after the publication of "Bartleby." These tales of white-collar workers have since been drawn into comparison in terms of, for instance, alienation and dehumanization-"Both Bartleby and Gregor are physically and psychologically screened off or locked away so that they are unable to communicate meaningfully with other human beings" (Duncan, 1991, p. 119)-but insufficient attention has been paid to how both office-fiction works are Gothicized. "Gothicizing is the antithesis of pastoralizing," Ken Egan argues in his study of the American Renaissance, "for it is the process of turning the canny into the uncanny" (1997, p. 28). In Melville's and Kafka's Gothicized stories, this process expresses itself as an integration of office and house, and thus work and life. Moreover, Gothicizing the stories allows an exploration of some other story, which can also be Gothicized by locating its Japanese protagonist as an international Bartleby like Gregor. The Gothicization of office fiction is therefore achievable through the diversification of Bartleby. Melville has his narrator liken this inscrutable character to an isolated castaway in the midst of the Atlantic Ocean: " $[\mathrm{H}] \mathrm{e}$ seemed alone, absolutely alone in the universe. A bit of wreck in the mid Atlantic" (1997, pp. 37-38). Bartleby does seem all alone in the universe of the office, but he is never alone in the literature of the office as an underexplored space of the Gothic, wherein his transnational kinsmen have awaited to be rediscovered as Bartlebys. Overall, rereading office fiction with this intertextual mindset can be expected to make discoveries about what has been overlooked when it comes to the office. As we shall see, office space is full of potential for transformation from an actual place of work into an integral part of the discourse of the Gothic.

\section{"Bartleby," or the Gothic}

The rediscovery of Melville was by no means separable from that of "Bartleby." As Talley Sharon notes, "Unlike most of Melville's stories, which have been generally acknowledged only since the 1960s, 'Bartleby' has consistently been singled out for recognition since the Melville Revival of the 1920s" (2007, p. 85). Melville was 
well ahead of his time, and so was "Bartleby." It was written when office work was much less natural than physically demanding jobs (e.g., farming and building) and when the office was deemed an unfit subject for literature. As remarked by Nikil Saval, "Clerks were once a rare subject in literature. Their lives were considered unworthy of comment, their workplaces hemmed in and small, their work indescribably dull. And yet one of the greatest of short stories is about a clerk" $(2015$, p. 9). This clerk is none other than Bartleby.

One of the most Gothic moments in "Bartleby" occurs when Bartleby appears at the office. "In answer to my advertisement," the lawyer-narrator reflects, "a motionless young man one morning, stood upon my office threshold, the door being open, for it was summer. I can see that figure now-pallidly neat, pitiably respectable, incurably forlorn! It was Bartleby" (p. 24). The youngster was standing upon the threshold rather than walking through the door. Taking this already-thereness as the earliest indication of his ghostly presence, William Vaughn examines Bartleby's supernatural existence described in such terms as "ghost," "haunt(ing)," and "cadaverous(ly)." Central to his view is that Bartleby haunts the office and therefore that "Bartleby' could be read as one of the great ghost stories in American literature" (1999, p. 537). To be sure, Bartleby seems as insubstantial as a ghost: he looks quite pallid, eats next to nothing, and has scarcely "anything ordinarily human about him" (p. 25). Bartleby's ghostliness is the driving force of the narrative. It is so haunting to the lawyer that he goes so far to say that Bartleby's trackless history is "an irreparable loss to literature" (p. 18). Of note in this connection is that the lawyer's obsession about his exemployee overlaps that about his ex-office-the chancery office abolished by the State Constitution of 1846. "It was not a very arduous office," he reflects, "but very pleasantly remunerative" (p. 19). For the lawyer, the office remains as haunting as Bartleby. His Gothic-sounding narrative can then be seen to come from his obsessive memory of the place as well as the person.

Vaughn contends that "Bartleby" is "a tale of the two characters who fail to connect" (p. 535). Such an interpretation typifies an oft-discussed aspect of "the Bartleby Industry," for "the most widely accepted contemporary interpretations of 'Bartleby' have centered upon the theme of the brotherhood of man or a variation thereof" (Craver and Plante, 1983, p. 132). To reemphasize, however, Gothic fiction is primarily concerned with the compelling power of place over people. In fact, "Bartleby" requires an ecological as well as interpersonal perspective when it comes to its office setting. Bartleby places himself on the work-life continuum. While abandoning his clerkship with the famous five words, "I would prefer not to," he refuses to abandon his relationship with his workspace, to which the lawyer refers as "his hermitage." Why does the scrivener make his home in the office? This question concerns itself with what the office looks like to him and how it affects him. As a newly-hired employee, Bartleby is assigned a cubicle in the lawyer's doored room: he has both a door separating him from the other two scriveners and a screen dividing him from the lawyer. In addition to the door whose ground glass has the power to place the two scriveners under panoptic supervision, the screen serves to retain the lawyer's privacy in the office as a society of its own. Bartleby takes advantage of this layout that ensures him an undefined space of privacy: he is put in contact with the others, but at the same time he is insulated from them. As early as his third day at work, he refuses to do anything requested. Of more import is that he confines himself to his semi-closed space where he is invisibly present like a ghost. Notably, as shown below, his confinement is the embodiment of connections-connections between work and life and between him and his kinsman, Gregor.

\section{Work-life breakdown}

Bartleby's hermitage is where he leads a semiprivate existence. More Gothically significant is that it is also where he leads a practically private existence. When he emerges from within the office on one Sunday, the lawyer finds him occupying this workplace:

Quite surprised, I called out; when to my consternation a key was turned from within; and thrusting his lean visage at me, and holding the door ajar, the apparition of Bartleby appeared, in his shirt sleeves, and otherwise in a strangely tattered dishabille, saying quietly that he was sorry, but he was deeply engaged just then, and-preferred not admitting me at present. In a brief word or two, he moreover added, that perhaps I had better walk round the block two or three times, and by that time he would probably have concluded his affairs. (p. 38)

The man who appeared from within the office was "the apparition of Bartleby." No longer was he an office worker; he was now an office dweller. His ghostliness stems from the disconnection between his appearance and his workplace. One should hasten to note, however, that the passage above describes not only how supernatural he looks, but also how unnatural it looks to live in the office. In Gothic terms, Bartleby is initially characterized by his already-thereness, and this characteristic is reinforced by his always-thereness. It can be said, then, that his ghostliness embodies the connection between work and life.

The feeling of horror triggered by the dissolution of the worklife boundary illustrates the transcendental nature of the Gothic. As typified by Edgar Allan Poe's 1839 Gothic classic, "The Fall of the House of Usher," in which Roderick Usher who attempts (and fails) at premature burial of his twin sister, Madeline, Gothic writing has been closely associated with temptations to transgress rules, cross boundaries, and overpass limits (and more often than not with such temptations that are prone to result in death and destruction). Drawing on Poe's 1840 defense of his stories against the criticism that his sources are all Germanic-"If in many of my productions terror has been the thesis, I maintain that terror is not of Germany, but of the soul" (1978, p. 473)-the coeditors of the essay collection entitled "Transnational Gothic" champion his attempt to universalize terror and thus the Gothic: "The Gothic springs from a universal impulse toward darkness, whether it is a personal sense of loss and fear of the collective guilt of a nation regarding troubling histories relating to race, removal of indigenous peoples, xenophobia, disinheritance of the poor, or any number of other problematic actions and attitudes of nations" (Elbert and Marshall, 2016, p. 1). As long as such an impulse is embedded in the Gothic, it will continuously lead us into the darkness that exists among nations as well as within ourselves, among their histories as well as within our memories. "In the work of terror," Gothic scholar David Punter notes, "history and memory are no longer stable; or rather, they are stripped of the illusion of stability and continuity, and we find ourselves in a darker world where we can no longer control the boundary between inner and outer" (2009, p. 249). The office that obsesses Bartleby is an epitome of this blind world: it presents itself as an entire universe wherein there is no boundary between work and life, "between inner and outer."

Bartleby takes absolutely no interest in fulfilling such general needs and wants as adequate nutrition and monetary value. One can readily assume that the purpose of his office dwelling is not to meet his basic need of housing. The point here is that his haunting shows how powerfully office space can affect one's life. "Bartleby" is arguably the most classic example of office fiction that demonstrates an innate affinity to Gothic fiction, including "The Metamorphosis." If "the apparition of Bartleby" horrifies his 
employer, then the transformation of Gregor horrifies his superior as well as his family members who live with him in an apartment house:

He had to edge himself slowly round the near half of the double door, and to do it very carefully if he was not to fall plump upon his back just on the threshold. He was still carrying out this difficult maneuver, with no time to observe anything else, when he heard the chief clerk utter a loud "Oh!"-it sounded like a gust of wind-and now he could see the man, standing as he was nearest to the door, clapping one hand before his open mouth and slowly backing away as if driven by some invisible steady pressure. (Kafka,1995, p. 100)

The man behind the door was, so to speak, the apparition of Gregor. No longer was he what he was before; he was now far from what used to be him. The Gothic irony of his animalization is that while feeling an animal urge to action- "I'm willing to work; traveling is a hard life, but I couldn't live without it" (p. 101) - he falls into an increasing state of inaction, thereby situating himself as an imperiled and confined protagonist as seen in the Gothic. The Gothic horror moment in the above-quoted passage can thus be viewed to exemplify the disconnection between mind and body. At the same time, however, as argued below, it does portray the connection between work and life, namely the connection suggestive of Gregor's Gothic kinship with Bartleby.

When the chief clerk enters the apartment, the third-person narrator refers time and again to him as "the visitor." Actually though, he acts as a superior who warns his subordinate that he is in danger of losing employment. Nothing in this officious clerk's behavior suggests that he is aware of stepping into the private life of the Samsas. Gregor, the breadwinning son in an average middle-class family, has separated his life from his work by scoring a room of his own, in which he amuses himself by doing fretwork. As shown above, however, he opens the door that has served as the dividing line between the private and the public, thus confronting the breakdown of work-life balance. The prelude to this breakdown can be found in the opening scene where he awakens from uneasy dreams. Given that he has made an unsuccessful career move from clerkship to salesmanship to support his family- "Oh God, he thought, what an exhausting job I've picked on! Traveling about day in, day out. It's much more irritating work than doing the actual business in the office" (p. 89) - his subconscious uneasiness is about his traveling job and his worsening position in the company. Indeed, even when he realizes his overnight transformation, his most pressing concern is not to restore his personhood, but to catch the train for work.

Gregor's metamorphosis exerts no significant influence on his self-consciousness as a traveling salesman, which is to say that "The Metamorphosis" is undeniably Gothic. Since he quit his office job, he has been confined to the world of terror, wherein he has faced pressure from inside and outside-from his family who expects him to repay their debts and from his company "where the smallest omission at once gave rise to the gravest suspicion!" (p. 94). So enormous is the pressure that he identifies himself as a company employee rather than a family member even when at home. Not only does he oversleep for work, but also oversteps the borders between work and life. Just like Bartleby's ghostliness, Gregor's grotesqueness manifests itself as the collapse of work-life separation. Drawing professionally structured parallels between Le Fanu's "Green Tea" and Bram Stoker's Dracula, William Hughes seeks answers to the seemingly elusive nature of the Gothic and concludes with conviction: "Beyond these two most obvious of case-studies, many further texts undoubtedly lie" (2017, p 35). This statement conveys that Gothic fiction studies shapes and reshapes itself through constant exploration of affinities between texts. Now that Kafka's Gothic narrative has been revealed to be thematically consistent with Melville's, these two are doubtless among those texts characteristic of the Gothic. As stated earlier, the practice of intertextuality is thus instrumental in approaching the macrocosmic universe of the Gothic. The arguments that follow will continue to be made with in mind the intertextual relations between "Bartleby" and "The Metamorphosis."

\section{Kafka's house imagery and Samsa's dynamic family}

When he becomes reluctant to do any of his tasks as a law copyist, Bartleby confines himself to his workspace. This Gothic action was reportedly relevant to his author's struggle with what is called "writer's block." Similarly, when he becomes unable to do any of his duties as a traveling salesman, Samsa has no option than to confine himself to his room. This Gothic inaction was presumably reflective of his author's problem with what is called "work-life balance." As Sarah Stodora puts it in her article "Franz Kafka Made a Stunning Observation on Work-Life Balance While Dying from Tuberculosis," Kafka's diaries, which cover the period from 1910 (the year when he set out to write "The Metamorphosis") to 1923 (the year just before his death at the age of forty), were not only accounts of his everyday life but also manuscripts of what was to become masterpieces of world literature. Her point is that "Kafka was hardly able to separate the writing of literature from life itself," i.e., "Kafka's inability to envision any kind of what we today call work-life balance" (Stodora, 2016). It should be said in this context that among the most salient features of his diaries are his architectural descriptions, as cited by David Spurr:

I want to construct myself (will ich mich dann aufbauen), says Kafka, like someone who has an unsafe house and who wants to build a new one next to it by using the materials of the old house. But it is bad (schlimm) if while he is doing so his strength gives out, so that now instead of having an unsafe but fully built house, he has one that is half destroyed and another only half built, and so nothing. (2012, pp. 87-88)

This passage uncovers key insights into the writings of Kafka. If he made no fine distinction between himself and literature, his use of unsafe-house imagery for his selfhood suggests that he considered his work to be as such-that is, an unsafe architecture as depicted in Gothic tales like "The Fall of the House of Usher." This suggestion lends itself to the Gothicization of "The Metamorphosis." Gregor's grotesque mutation at the outset of the story declares how urgent it is for his family to deal with their unsafe house. As we will see, they transform the house from a place to live into a place to work and retransform it into a house to be abandoned. Such dynamic transformation is indeed illustrative of having "one that is half destroyed and another only half built, and so nothing."

Having seen their sole breadwinner confined to his room, Gregor's family-Mr. and Mrs. Samsa and his sister Grete-turns their house from a living space into a working space. As an interested party, they part with their accessories now unnecessary for them and take in three lodgers to help with their household income. On top of that, they are obliged to find themselves jobs: Mr. Samsa works as a bank security guard in order to support his family again; Mrs. Samsa works from home as a seamstress for an underwear firm; Grete works for a shop but prepares for her career as a stenographer. While doing their own things, they treat the lodgers by, for example, performing music and providing meals. Grete has played the violin and dreams of going to the conservatory to pursue lessons, but she has no other opportunity 
than to perform for those who lounge about the living room. Now the family dine in the kitchen; they offer their living room as an entertainment space. Since there is no room for family gathering, they no longer engage in intimate conversations. An obvious example of their dramatic transformation from a Gemeinschaft into a Gesellschaft is found in Mr. Samsa. Like Gregor, he oversteps the boundary between work and life:

With a kind of mulishness his father persisted in keeping his uniform on even in the house; his dressing gown hung uselessly on its peg and he slept fully dressed where he sat, as if he were ready for service at any moment and even here only at the beck and call of his superior. As a result, his uniform, which was not brand-new to start with, began to look dirty, despite all the loving care of the mother and sister to keep it clean, and Gregor often spent whole evenings gazing at the many greasy spots on the garment, gleaming with gold buttons always in a high state of polish, in which the old man sat sleeping in extreme discomfort and yet quite peacefully. (p. 123)

Now that the apartment house operates as the family's home office in which, as stated above, the mother and the daughter do their own businesses, from stitching to learning shorthand to serving nonfamily members, it comes as no surprise that "even in the house," the father has his uniform on, sleeps fully clothed, and sits sleeping "in extreme discomfort and yet quite peacefully." Nor is it necessarily unreasonable for him to deal harshly with Gregor. The father attacks the transformed son several times, for, in the former's eyes, the latter looks like a noxious insect in the office as well as a black sheep of the family.

Whether suicide or otherwise, Gregor suffers death in his room -room, now barely furnished, in which he has quickly lost taste for any homelike meal. The end of his own life leads to the start of his family's new life: the story finishes with the family's reunion that enables his parents to find their daughter of seventeen summers regaining her status in the family by attaining womanhood. Gothically speaking, she is an unacknowledged heroine-in-peril, who transforms herself from a reactive victim into a proactive victor. Initially, she takes care of her transformed brother out of generosity, but later out of duty. While aspiring to attend the conservatory, she suffers from her family's financial hardship. In order to assist them, she finds a job in sales and seeks a career to better herself. Eventually, she wins support from her parents to remove Gregor. Symbolically enough, the story ends with her own metamorphosis into an adult so as to mark the end of the troubled situation of the Samsas. Thus comes the family's retransformation from business partners into blood relations, from a Gesellschaft into a Gemeinschaft. As a family of three, they decide to leave their work-life environment and to move to "a smaller and cheaper but also better situated and more easily run apartment, which Gregor had selected" (p. 139). This eventual decision prefigures the modern concept of work-life balance: the family will live by the belief that the office is not a place to live and nor is the house a place to work. The end of Kafka's Gothic tale is hence the end of the family's Gothic life with the apparition of Gregor, just as Melville's Gothic tale ends with the end of the lawyer's Gothic life with "the apparition of Bartleby." After his death, Gregor's body-which goes "completely dry and flat" (p. 137) - is removed from his selected house by an elderly widow hired as housekeeper for the Samsas. Similarly, after his removal from his occupied office, "the wasted Bartleby" (p. 50) is found dead by the lawyer and his hired caterer in an infamous prison called "The Tombs." As is very often the case with Gothic fiction, both stories close with death and destruction.

\section{Bartlebys international}

As we have seen, Bartleby and Gregor mirror one another. The former's occupation of the office turns the place into a house, and the latter's transformation in his house turns the place into an office. It is these dual settings that make each protagonist uncanny and ghostly: one lives a half-life as a cubicle dweller at work, and the other as a commercial traveler at home. Note that it was not until between the late 1970s and the early 1980s that the term "work-life balance" entered common parlance. The boundaries between work and other aspects of life had yet to become an issue in the times of Melville and Kafka, but they demonstrated, each in their own ways, that the work-life nexus can be an intimidating issue, that is to say, it can be the subject of the Gothic.

In her essay, "The Evolution of Gothic Spaces: Ruins, Forests, Urban Jungles," Carol Senf observes that "contemporary Gothic no longer depends on the conventions of castles, villains, and persecuted maidens but instead reveals people's fears of what is taking place around them" (2017, p. 260). The Gothic genre has, over hundreds of years, evolved into an everyday issue of fear. An early sign of this evolution was shown in "Bartleby" and "The Metamorphosis." Bartleby's ghostly existence frightens his employer who threatens him with removal. Likewise, Samsa's grotesque existence frightens his superior who threatens him with dismissal. One can refer to these fear-based relationships as prototypical of what was to haunt such office-worker protagonists as Bob Slocum in Joseph Heller's 1974 office novel, Something Happened:

In the office in which I work there are five people of whom I am afraid. Each of these five people is afraid of four people (excluding overlaps), for a total of twenty, and each of these twenty people is afraid of six people, making a total of one hundred and twenty people who are feared by at least one person. Each of these one hundred and twenty people is afraid of the other one hundred and nineteen, and all of these one hundred and forty-five people are afraid of the twelve men at the top who helped found and build the company and now own and direct it. $(1975$, p. 9)

The office is governed from within by the chain of fear. Significantly, this situation is the case with actual offices. As observed by an expert on office workplace issues, "many companies, operating in an age of terrifying economic uncertainty, still seem dominated by fear, poisoning the workdays of employees at all levels, from the CEO ruled by fear of scandal and bankruptcy to the middle manager afraid of being exposed as incompetent to the rank-and-file worker who fears losing his or her means of survival" (Glovinsky, 2010, p. 59). If the modern office is an everyday arena of interpersonal relations between those who fear and those who are feared, then it is an evolutionary form of the Gothic. In both fact and fiction, Gothic spaces are increasingly becoming affinitive to office spaces. It may come as an utter surprise that Melville and Kafka were already (albeit quietly) writing the tales of this affinity, respectively in the antebellum and prewar periods in the New and Old Worlds.

Office fiction travels well with the Gothic. In the world of office fiction Gothicized, Bartleby's closest international cousins include Gregor. Having said that, one question comes to mind: who else can be an international Bartleby? An answer to this question is found in "Evenings at the Pool," the story by the Japanese postwar novelist, Junzo Shono, which was anthologized in The Columbia Anthology of Modern Japanese Literature: From 1945 to the Present. This 1954 Akutagawa Prize-winning work tells of Mr. Aoki, an ex-employee who was recently dismissed for his misappropriation of company funds. As the story unravels, Mrs. Aoki comes to realize that her husband was always working in constant fear at the office. Among the most terrifying experiences he 
relates to her is about some white flash he used to see in the office. "It's like a ghost," he says, "maybe-like some strange, lonely spirit" (1992, p. 45). This ghostly flash remains uncertain throughout his narrative. What is certain is that he perceives the office as haunted by something already and always there. Whether for this reason or not, he is of the opinion that many other employees are also held in the grip of fear. When his story comes to an end, the third-person narrative speculates on why those white-collar workers, including himself, feel an unspecified fear at home as well as at work:

But again, what is it that so frightens all these men? It is neither a particular groups of individuals, nor anything else you can really put your finger on. It haunts them even at home, in their times for resting and relaxing with their lives and children. It enters even into their dreams and threatens them in their sleep. It's what brings the nightmares that terrorize them in the middle of the night. (p. 46)

What frightens them is "it." Since it is unidentified, it is uncanny to them. What is more, it haunts them "even at home." They dream about it and awakens from it as an uneasy dream. The sphere of their life is hence an extension of that of their work. It can then be said that they, including Mr. Aoki, whose suicide death in the swimming pool is rather implicitly suggested at the end of the story, are all distant cousins of Bartleby and Gregorthat they are all Bartlebys. Melville's and Kafka's Gothic tales of the office and the house transformed into an office will continuously furnish the key to illuminating fiction featuring a wide diversity of Bartlebys.

More Bartlebys can be discovered by placing more stories in perspective of the Gothic. As Clive Bloom declares in his book on the Gothic, "Other genres owe much to gothic concerns and neither detective fiction nor science fiction can be separated in their origins from such an association" (2007, p. 2). Besides detective and science fiction, one of those genres is office fiction that delineates every sphere of life-of course, not excluding work life-as subject to Gothicization. After all, Gothic fiction is an ever-expanding universe in which the walls come tumbling down between office and house, between work and life, and ultimately between the Gothic and the non-Gothic. This genre can no longer simply refer to the so-called genre fiction. With its obsessive focus on the house, it is potentially capable of housing other genres of fiction, certainly including office fiction.Data availability Data sharing is not applicable to this paper as no datasets were generated or analyzed.

\section{Data availability}

Data sharing is not applicable to this paper as no datasets were generated or analyzed.

Received: 27 July 2018 Accepted: 10 October 2018

Published online: 06 November 2018

\section{Notes}

1 For studies of American office fiction, including Nathanael West's Miss Lonelyhearts (1933), Chuck Palahniuk's Fight Club (1996), and Don DeLillo's Cosmopolis (2003), see, for example, Kobayashi (2015).

\section{References}

Bloom C (2007) Introduction: Death's own backyard. In: Bloom C (ed) Gothic horror: a guide for students and readers. Palgrave Macmillan, New York, $p$ $1-24$

Craver D, Plante P (1983) Bartleby or, the ambiguities. Stud Short Fict 20(2/ 3):132-137

DeLillo D (2011) Americana. Penguin Books, London
Duncan LF (1991) Herman Melville's 'Bartleby' and Franz Kafka's 'The Metamorphosis': a study in thematic affinities and narrative technique. Comparatist 15:116-128

Egan K (1997) The Riven Home: Narrative Rivalry in the American Renaissance. Susquehanna University Press, London

Elbert M, Marshall BM (2016) Introduction. In: Elbert M, Marshall BM (eds) Transnational Gothic: literary and social exchanges in the long nineteenth century. Routledge, London, p 1-14

Glovinsky C (2010) Making peace with your office life: end the battles, shake the blues, get organized, and be happier at work. St. Martin's Griffin, New York

Heller J (1975) Something happened. Ballantine, New York

Hughes W (2013) Historical dictionary of Gothic literature. The Scarecrow Press, Lanham

Hughes W (2017) The casework relationship: Le Fanu, Stoker and the rhetorical context of Irish Gothic. In: Marius-Mircea C (ed) Dracula: an international perspective. Palgrave Macmillan, Cham, Switzerland, p 21-37

Kafka F (1995) The metamorphosis. The complete stories. Trans: Muir W, Muir E. Schoken Books, New York, p 89-139

Kobayashi M (2015) Bartlebys diversified: Miss Lonelyhearts and office fiction. The Journal of the American Literature Society of Japan 14:39-55

McCall D (1989) The Silence of Bartleby. Cornell University Press, Ithaca

Melville H (1997) Bartleby, the scrivener: a story of Wall-Street. The Complete Shorter Fiction. Everyman's Library, London, p 18-51

Poe EA (1978) Preface. In: Mabbott TO (ed) Collected Works of Edgar Allan Poe, Vol. II: Tales and Sketches, 1831-1842. Belknap Press of Harvard University, Cambridge, p 473-474

Punter D (2009) Terror. In: Marie Murvey-Roberts (ed) The Handbook of the Gothic, 2nd edn. Palgrave Macmillan, Basingstoke, p 243-249

Saval N (2014) Bartlebys all! Dissent 61(4):22-26

Saval N (2015) Cubed: a secret history of the workplace. Anchor, New York

Senf C (2017) The evolution of gothic spaces: Castles, ruins, urban jungles. In: Marius-Mircea C (ed) Dracula: an international perspective. Palgrave Macmillan, Cham, Switzerland, p 259-274

Sheldrick C (2014) The pleasures of reading: a Booklover's alphabet. Libraries Unlimited, Santa Barbara

Shono J (1992) Evenings at the pool. Still Life and Other Stories. Trans: Lammers WP. Stone Bridge Press, Berkeley

Spurr D (2012) Architecture and modern literature. University of Michigan Press, AnnArbor

Stodorah S (2016) Franz Kafka made a stunning observation on work-life balance while dying from tuberculosis. Business Insider. https://www.businessinsider. com.au/franz-kafka-on-work-life-balance-2015-2 Accessed 8 Sep 2018

Talley S (2007) Student companion to Herman Melville. Greenwood Press, Westport

Vaughn W (1999) Moving from privacy: "Bartleby" and otherness. Centen Rev 43 (3):535-564

\section{Acknowledgements}

The present study is supported by JSPS KAKENHI Grant Number JP16K02496.Data availabilityData sharing is not applicable to this paper as no datasets were generated or analyzed.

\section{Additional information}

Competing interests: The author declares no competing interests.

Reprints and permission information is available online at http://www.nature.com/ reprints

Publisher's note: Springer Nature remains neutral with regard to jurisdictional claims in published maps and institutional affiliations.
Open Access This article is licensed under a Creative Commons Attribution 4.0 International License, which permits use, sharing, adaptation, distribution and reproduction in any medium or format, as long as you give appropriate credit to the original author(s) and the source, provide a link to the Creative Commons license, and indicate if changes were made. The images or other third party material in this article are included in the article's Creative Commons license, unless indicated otherwise in a credit line to the material. If material is not included in the article's Creative Commons license and your intended use is not permitted by statutory regulation or exceeds the permitted use, you will need to obtain permission directly from the copyright holder. To view a copy of this license, visit http://creativecommons.org/ licenses/by/4.0/.

(c) The Author(s) 2018 